\title{
IDENTIFICATION OF GH|ALUI AND GHR|ALUI GENES POLYMORPHISMS IN INDONESIAN BUFFALO
}

\author{
E. Andreas ${ }^{1}$, C. Sumantri ${ }^{1}$, H. Nuraini ${ }^{1}$, A. Farajallah ${ }^{2}$ and A. Anggraeni ${ }^{3}$ \\ ${ }^{1}$ Faculty of Animal Science, Bogor Agricultural University, \\ Jl.Agatis, Darmaga Campus, Bogor 16680 - Indonesia \\ ${ }^{2}$ Faculty of Mathemathics and Natural Science, \\ Bogor Agricultural University, Jl. Agatis, Darmaga Campus, Bogor 16680 - Indonesia \\ ${ }^{3}$ Indonesian Research Institute for Animal Production, \\ Jl. Veteran III, Desa Banjarwaru, Ciawi, Bogor 16002 - Indonesia \\ Corresponding E-mail: erykandreas@yahoo.com
}

Received September 20, 2010; Accepted November 23, 2010.

\begin{abstract}
Growth hormone $(\mathrm{GH})$ is an anabolic hormone which sintesized and secreted by somatrotop cell in pituitary anterior lobe. GH exert its effect on growth and metabolism by interacting with a specific receptor on the surface of the target cells. Growth hormone receptor (GHR) has been suggested as candidate gene for traits related to meat production in Bovidae. The objectives of this study were to identify polymorphism of GH and GHR genes in buffalo. The 452 DNA samples buffalo were collected from five populations in Indonesia (Siborong-Borong-Medan (65), Lebak-Banten (29), PandeglangBanten (180), Semarang-Central Java, and Mataram-West Nusa Tenggara (103)). A gene fragment of the $\mathrm{GH} \mid A l u \mathrm{I}$ gene at $432 \mathrm{bp}$ located on exon 3 and GHR|AluI gene at 298 bp on exon 10 were successfully amplified by using the techniques of a PCR (polymerase chain reaction) and genotyped by PCR-RFLP (restriction fragment length polymorphism) then -SSCP (single strand conformation polymorphism). The results showed no polymorphisms were detected in these genes. All buffaloes tested had LL genotype for locus GH|AluI and AA genotype for locus GHR $\mid A l u \mathrm{I}$.
\end{abstract}

Keywords: Buffalo, Growth Hormone, Growth Hormone Receptor, Polymorphism

\section{INTRODUCTION}

Authorized national livestock sector development is largely determined by the ownership, preservation and utilization of biological resources such as livestock animals that have been developed and are still maintained subsistence. Buffalo (Bubalus bubalis) is one large ruminants that has its own advantages for development because it can survive with lowquality of feed, tolerant to local parasites and such existence has been fused with social and cultural life of Indonesian farmers. Buffaloes maintained by the farmer in the traditional way used as a draft, meat production, organic fertilizer, leather and socio-cultural ritual. Thus, the local buffalo is a source of germplasm that can be used in order to increase food availability, to improve public welfare, to create employment and to generate foreign exchange. Animals that are genetically adapted to specific environmental condition, would be more productive because it can be developed using low cost, supporting the diversity of food, agriculture and culture, as well as effective in achieving the objectives of food security (FAO, 2000).

Growth hormone (GH) is an anabolic hormone synthesized and secreted by cells of lobe somatotrop in anterior pituitary (Ayuk and Sheppard, 2006). GH has an important role in the growth and postnatal development, growth tissue, lactation, reproduction, and proteins, lipids and carbohydrates metabolism (Akers, 2006; ThidarMyint et al., 2008). GH gene diversity in Japanese Black cattle influenced carcass characteristics and fatty acid composition (Ardiyanti et al., 2009). Growth hormone receptor (GHR) is a transmembrane protein that binds GH by high affinity and specificity. Receptor expression is required to produce the cellular activity of GH. This indicates that the changes in GHR function can affect the ability of GH binding and GH activity in target tissues (Di Stasio et al., 2005). 
Information of diversity using molecular approaches at the local buffalo in Indonesia is still very rare. Diversity of functional genes has been widely used as an auxiliary marker selection on some livestock commodities, combined with optimal maintenance management. The aim of this study was to gather information GH and GHR gene diversity at the local buffalo in Indonesia.

\section{MATERIALS AND METHODS}

\section{DNA Sample}

DNA samples obtained from blood and buffalo meat. The blood samples were used as a source of as much as 320 DNA samples originating from five different regions, namely 65 samples from Siborong-Borong (North Sumatera Province), 29 samples from Lebak (Banten Province), 48 samples from Pandeglang (Banten Province), 75 samples from Semarang (Central Java Province), and 103 samples from Mataram (West Nusa Tenggara Province), while the samples that were used as a source of meat as much as 132 DNA samples were from Pandeglang (Banten Province).

\section{Primer}

Primers to amplify gene segments of GH followed Balogh et al. (2009), with forward primer 5'-CGGACCGTGTCTATGAGAAGC TGAAG-3' and reverse primer 5'GTTCTTGAGCAGCGCGTCGTCA-3'. The amplified product length was 432 bp long. Primers to amplify GHR gene segment was designed using software primer designing tool (http://www.ncbi.nlm.nih.gov/tools/primaryblast/index.cgi), with the default option for primers 20-24 nucleotides long, and PCR products $200-500$ bp long. Forward primer 5'GCTTACTTCTGCGAGGTAGACGC-3' and reverse primer 5'-GTCTGTGCTCACATAGC CAC-3'. The amplified product length was 298 bp long.

\section{DNA Extraction}

DNA was extracted from blood and buffalo meat. Extraction procedure followed the phenolchloroform method (Sambrook and Russell, 2001) was modified, with the following procedure:

\section{Sample preparation.}

Meat samples within alcohol were as much as $70 \mathrm{mg}$, whereas the blood in the alcohol were as much as $200 \mu 1$. Sample was inserted to a 1.5 $\mathrm{ml}$ tube. Alcohol was eliminated from the sample by adding distilled water until $1000 \mu 1$, and left in room temperature for 20 minutes. Then it was precipitated by centrifugation at a speed of 8000 rpm for 5 minutes.

\section{Protein degradation}

The samples were cleared from alcohol and added by $200 \mu \mathrm{L} 1 \mathrm{x}$ STE (sodium tris EDTA), 40 $\mu \mathrm{L}$ sodium dosesil sulfate $10 \%$, and $20 \mu \mathrm{l}$ proteinase $\mathrm{K}(5 \mathrm{mg} / \mathrm{ml})$. The mixture ware incubated overnight at $55{ }^{\circ} \mathrm{C}$ temperature while shaken gently.

\section{Organic material degradation}

After incubated, samples were added by 400 $\mu 1$ phenol solution, $400 \mu \mathrm{L}$ choloform:isoamyl alcohol (24:1), and $40 \mu \mathrm{L} 5 \mathrm{M} \mathrm{NaCl}$. Then, the mixture was shaken at room temperature for one hour.

\section{DNA precipitation}

Samples were centrifuged at a speed of 5000 rpm for 10 minutes to separate the water phase with phenol phase. Water phase was transferred in a new tube with the volume measured. DNA molecules deposited by adding a $2 \mathrm{x}$ volume of alcohol absolute and $0.1 \mathrm{x}$ volume of $5 \mathrm{M} \mathrm{NaCl}$. Then the mixture was incubated at a temperature of $-20{ }^{\circ} \mathrm{C}$ over night. Subsequent DNA precipitation was by centrifugated at a speed of 12 $000 \mathrm{rpm}$ for 10 minutes. Obtained DNA precipitate was washed by $70 \%$ alcohol, and then precipitated again. Precipitated DNA clean from alcohol restored by adding $100 \mu 1 \mathrm{TE}$ (Tris EDTA). DNA samples were stored at $-20{ }^{\circ} \mathrm{C}$ and ready for use.

\section{Amplification of GH and GHR Genes}

Amplification of $\mathrm{GH}$ and GHR fragment were done by using PCR (polymerase chain reaction) methods. Reagents used for amplification of both target fragment were a $2 \mu \mathrm{L}$ sample DNA, each primer $25 \mathrm{pmol}, 200 \mu \mathrm{M}$ dNTPs mixture, $1 \mathrm{mM} \mathrm{MgCl} 2$, and 0.5 units of DreamTaq $^{\mathrm{TM}}$ DNA Polymerase and $1 \mathrm{x}$ buffer (Fermentas) in total solution $25 \mu \mathrm{L}$. Amplification in vitro within GeneAmp ${ }^{\circledR}$ PCR System 9700 (Applied Biosystems ${ }^{\mathrm{TM}}$ ) done with the condition of pra-denaturation at $94^{\circ} \mathrm{C}$ for 5 minutes, 35 cycles consisting of denaturation at $94^{\circ} \mathrm{C}$ for 45 
seconds, annealing primers at $62^{\circ} \mathrm{C}$ for 45 seconds and extention of new DNA at $72^{\circ} \mathrm{C}$ for 1 minute, and the final extention at $72^{\circ} \mathrm{C}$ for 5 minutes.

\section{Genotyping by using RFLP Method}

Determination of genotypes of each individual was done by using restriction fragment length polymorphism (RFLP), follow by visualized on $2 \%$ agarose gel with $0.5 \mathrm{x}$ TBE buffer (tris borate EDTA) at $100 \mathrm{~V}$ for 40 minutes. Gel was stained by ethidium bromide, and visualized on UV transiluminator. Cutting enzyme that is used for both sides of the target gene was AluI.

\section{Identification of Polymorphism by using PCR- SSCP and Sequencing Methods}

Diversity detection with PCR-SSCP approach performed as an alternative in the identification of GH and GHR gene diversity related to quality of buffalo meat. PCR-SSCP analysis was done by resolved the single pieces of DNA in PAGE (Polyacrilamide gel electrophoresis) $8 \%$. Electrophoresis process was conducted at $100 \mathrm{~V}$ for 16 hours. Visualized of single strand DNA bands were done by sensitive silver staining methods. In addition to PCR-SSCP, the eight samples were sequenced to indentify the difference DNA sequence of GH and GHR gene were observed by DNA sequence GenBank.

\section{Genotype and Allele Frequency}

Genotype frequency represents the ratio of a genotype to total population. Allele frequency is a ratio of an allele to the overall allele at a locus in the population. Mathematical model genotype and allele frequency (Nei and Kumar, 2000) is represented as follows:

$$
\begin{gathered}
X_{\mathrm{ii}}=\frac{\mathrm{n}_{\mathrm{ii}}}{\mathrm{N}} \times 100 \% \\
\mathrm{X}_{\mathrm{i}}=\frac{\left(2 \mathrm{n}_{\mathrm{ii}}+\sum_{\mathrm{i} \neq \mathrm{j}} \mathrm{n}_{\mathrm{ij}}\right)}{2 \mathrm{~N}}
\end{gathered}
$$

where :

$\mathrm{x}_{\mathrm{ii}}=\mathrm{ii}^{\text {th }}$ genotype frequency

$\mathrm{n}_{\mathrm{ii}}=$ number sample of ii genotype

$\mathrm{n}_{\mathrm{ij}} \quad=$ number sample of $\mathrm{ij}$ genotype

$\mathrm{N}=$ total sample

$\mathrm{x}_{\mathrm{i}}=\mathrm{i}^{\text {th }}$ allele frequency

\section{RESULTS AND DISCUSSION}

\section{Amplification of Buffalo GH and GHR Genes Fragment}

Amplification of GH and GHR genes fragment was carried on GeneAmp ${ }^{\circledR}$ PCR System 9700 (Applied Biosystems ${ }^{\mathrm{TM}}$ ) with temperature of $62^{\circ} \mathrm{C}$. The amplified gene fragments were visualized on $1.5 \%$ agarose gel (Figure 1). The amplified product (amplicon) length GH gene fragment was $432 \mathrm{bp}$, including $55 \mathrm{bp}$ of $4^{\text {th }}$ exon, $4^{\text {th }}$ intron, and $99 \mathrm{bp}$ of $5^{\text {th }}$ exon (Balogh et al., 2009). The amplicon length of GHR gene fragment was $298 \mathrm{bp}$ located in $10^{\text {th }}$ exon (Genbank Access No. AY053546).

\section{Identification of GH and GHR Genes by Using PCR-RFLP Method}

Determination of $\mathrm{GH}$ and GHR gene genotypes in this study was done by PCR-RFLP method using $A l u \mathrm{I}$ which have cutting site AG|CT. Based on DNA sequences of GH genes amplified segment there were three sites $A l u \mathrm{I}$ cutting, which produced fragments of length $20,51,96$, and 265 $\mathrm{bp}$, known as the leucine allele $(\mathrm{L})$. There was a substitution from $\mathrm{C}$ to $\mathrm{G}$ at position 1758 (Lucy et al., 1993), so the produces fragments of length 20 , 147 , and $265 \mathrm{bp}$, known as the valine allele (V) (Balogh et al., 2009). Visualization on 2\% agarose gel showed that the GH $\mid A l u \mathrm{I}$ locus the fifth buffalo population was monomorphic. The LL genotype were found in a total sample (Figure 2).

Restriction by using AluI enzyme done on the amplicon of GHR gene fragment (GHR $\mid A l u \mathrm{I})$ produces fragment of length 81 and $217 \mathrm{bp}$, known as the A allele. Some studies showed the substitution at position 256 in cattle (Genbank accession number AY053546), from A to G. These changes caused a loss of enzyme recognition sites of $A l u \mathrm{I}$, so that produced fragment of the length 298 bp, known as the G allele (Ge et al., 2000; Di Stasio et al., 2005). Genotype found in buffalo in this research was AA genotype (Figure 3).

\section{Genetic Diversity of GH|AluI dan GHR $\mid A l u I$ Genes within Indonesian Buffalo}

Genetic diversity within a population can be used as a parameter in studying the population and evolutionary genetics, in addition, it can be used to identify and preserve the peoples in the population associated with the character of a special nature. Knowledge of the genetic diversity of a nation will be very useful for food security and continuous availability (Blott et al., 2003). 


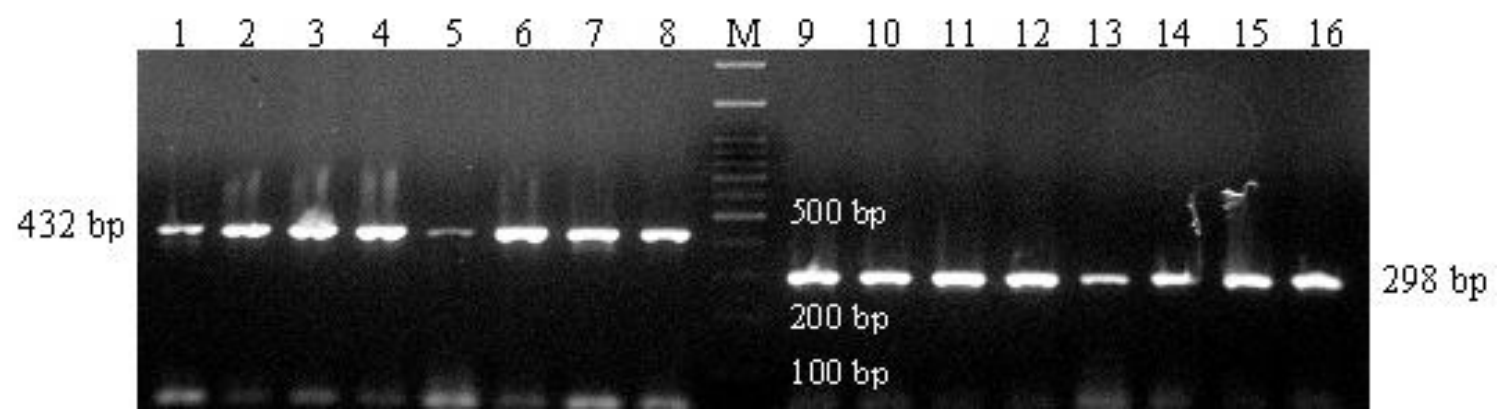

Figure 1. Visualization of the Amplicon of GH and GHR gene on 1.5\% Agarose gel. 1-8: GH gene Fragment, M: DNA Ladder 100 bp, and 9-16: GHR Gene Fragment

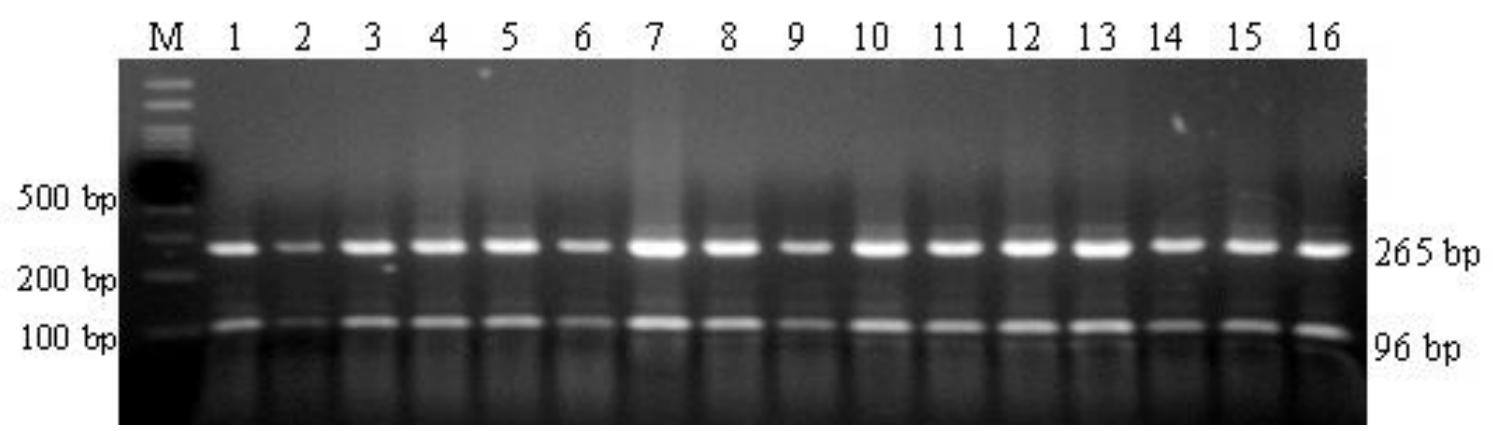

Figure 2. Visualization of the GH|AluI locus on $2 \%$ Agarose Gel. M: DNA Ladder $100 \mathrm{bp}$, 1-16: Buffalo Samples Genotype LL

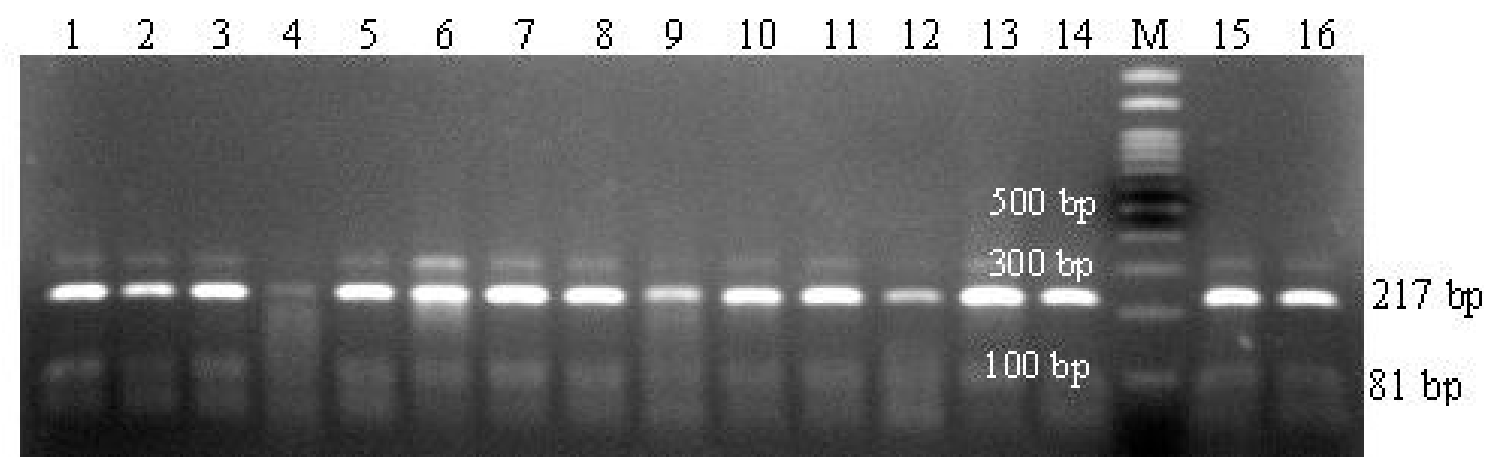

Figure 3. Visualization of the GHR|AluI locus on 2\% Agarose Gel. M: DNA Ladder 100 bp, 1-16: Buffalo Samples Genotype AA.

Level of diversity within populations can be drawn from the allele frequency. Allele frequency is a ratio of one allele relative to the overall allele found in one population. Information on genetic diversity of a population using multiple loci, can be described by the value of heterozygosity (Nei and Kumar, 2000). Genotypes and allele frequencies of $\mathrm{GH} \mid A l u \mathrm{I}$ locus is presented in Table 1 , while for the GHR $\mid A l u \mathrm{I}$ locus is presented in Table 2.

Genetic diversity based on molecular marker
$\mathrm{GH} \mid A l u \mathrm{I}$ and GHR $\mid A l u \mathrm{I}$ loci in buffalo were very low. This was indicated by the value of one genotype frequency and allele which had a value of 1, which marks the fixation process. Diyono (2009) showed that the GHRH|HaeIII and GH| MspI genes in buffalo from Banten Province were polymorphic, while for Pit-1|HinfI gene was monomorphic. Degree of heterozygosity for GHRH|HaeIII and GH|MspI genes was 0.49 and 0.05 , respectively.

Low diversity in buffalo can be caused by a 
Table 1. Genotype and Allele Frequency of the GH|AluI Locus

\begin{tabular}{lllllll}
\hline \multirow{2}{*}{ Population } & \multicolumn{1}{c}{ LL } & LV & & \multicolumn{3}{c}{ Allele } \\
\cline { 2 - 4 } \cline { 5 - 6 } Siborong-Borong (65) & $100(65 / 65)$ & 0 & & VV & & V \\
Lebak (29) & $100(29 / 29)$ & 0 & & & 1 & 0 \\
Pandeglang (180) & $100(180 / 180)$ & 0 & 0 & & 1 & 0 \\
Semarang (75) & $100(75 / 75)$ & 0 & 0 & & 1 & 0 \\
Mataram (103) & $100(103 / 103)$ & 0 & 0 & & 1 & 0 \\
Total (452) & $100(452 / 452)$ & 0 & 0 & & 1 & 0 \\
\hline
\end{tabular}

Table 2. Genotype and Allele Frequency of the GHR $\mid A l u$ I Locus

\begin{tabular}{lllllll}
\hline \multicolumn{1}{c}{ Population } & \multicolumn{3}{c}{ Genotype $(\%)$} & & \multicolumn{2}{c}{ Alelle } \\
\cline { 2 - 3 } \cline { 5 - 6 } & \multicolumn{1}{c}{ AA } & AG & GG & & A & G \\
\hline Siborong-Borong (65) & $100(65 / 65)$ & 0 & 0 & & 1 & 0 \\
Lebak (29) & $100(29 / 29)$ & 0 & & 0 & 1 & 0 \\
Pandeglang (180) & $100(180 / 180)$ & 0 & & & 1 & 0 \\
Semarang (75) & $100(75 / 75)$ & 0 & & & 1 & 0 \\
Mataram (103) & $100(103 / 103)$ & 0 & & & 1 & 0 \\
Total (452) & $100(452 / 452)$ & 0 & & & 1 & 0 \\
\hline
\end{tabular}

limited number of males in the population, and the high inbreeding frequency. The number of samples of male buffalo found in this study ( $20 \%$ of the total sample) was less when compared to samples of female buffaloes. The number of albino buffalo, can be used as one indicator of the high frequency of inbreeding. Nei and Kumar (2000) argued that the high frequency of inbreeding can reduce the diversity in the population.

\section{Identification of GH and GHR Genes by using PCR-SSCP Methods and Sequencing}

Polymerase chain reaction-single-strand conformation polymorphism (PCR-SSCP) is one further analysis method that utilizes PCR product. PCR-SSCP method is a reliable method of quickly detecting a mutation (Hayashi, 1991). This method is based on the assumption that the nucleotide acid changes would lead to changes in migration patterns on polyacrylamide gel nondenaturasi (Barroso et al., 1999). Mutation was detected from the differences in migration patterns from conformation of single strand DNA on polyacrylamide gels (Hayashi, 1991). Migration pattern of single strand DNA of GH and GHR gene fragment on PAGE in this study were uniform.

Analysis of nucleotide similarity of GH and
GHR gene sequencing results with the sequence of nucleotides in cattle and buffaloes in Genbank was done by BLAST method (http://blast.ncbi.nlm.nih.gov/Blast.cgi). Sequence of buffalo GH gene (Figure 4) did not reveal any base change from $\mathrm{C}$ to the $\mathrm{G}$ at position 1758 (Lucy et al., 1993; Balogh et al., 2009). The same thing happened to sequence of GHR gene fragment (Figugre 5), which did not reveal any base changes from A to $\mathrm{G}$ at position 256 (Ge et al., 2000; Di Stasio et al., 2005).

\section{CONCLUSION}

It can be concluded that the diversity of $\mathrm{GH}$ $A l u \mathrm{I}$ and GHR $\mid A l u \mathrm{I}$ genes in Indonesian buffalo was very low and showed no polymorphisms were detected in these genes. All buffaloes tested had LL genotype for locus GH|AluI and AA genotype for locus GHR $\mid$ AluI.

\section{ACKNOWLEDGMENTS}

The work was supported by Ministry of Agriculture Republic of Indonesia through the KKP3T 2009 project with contract no. 637/LB.620/I.1/2/2009. We would like to thanks to Directorate General of Livestock (DGLS)- 


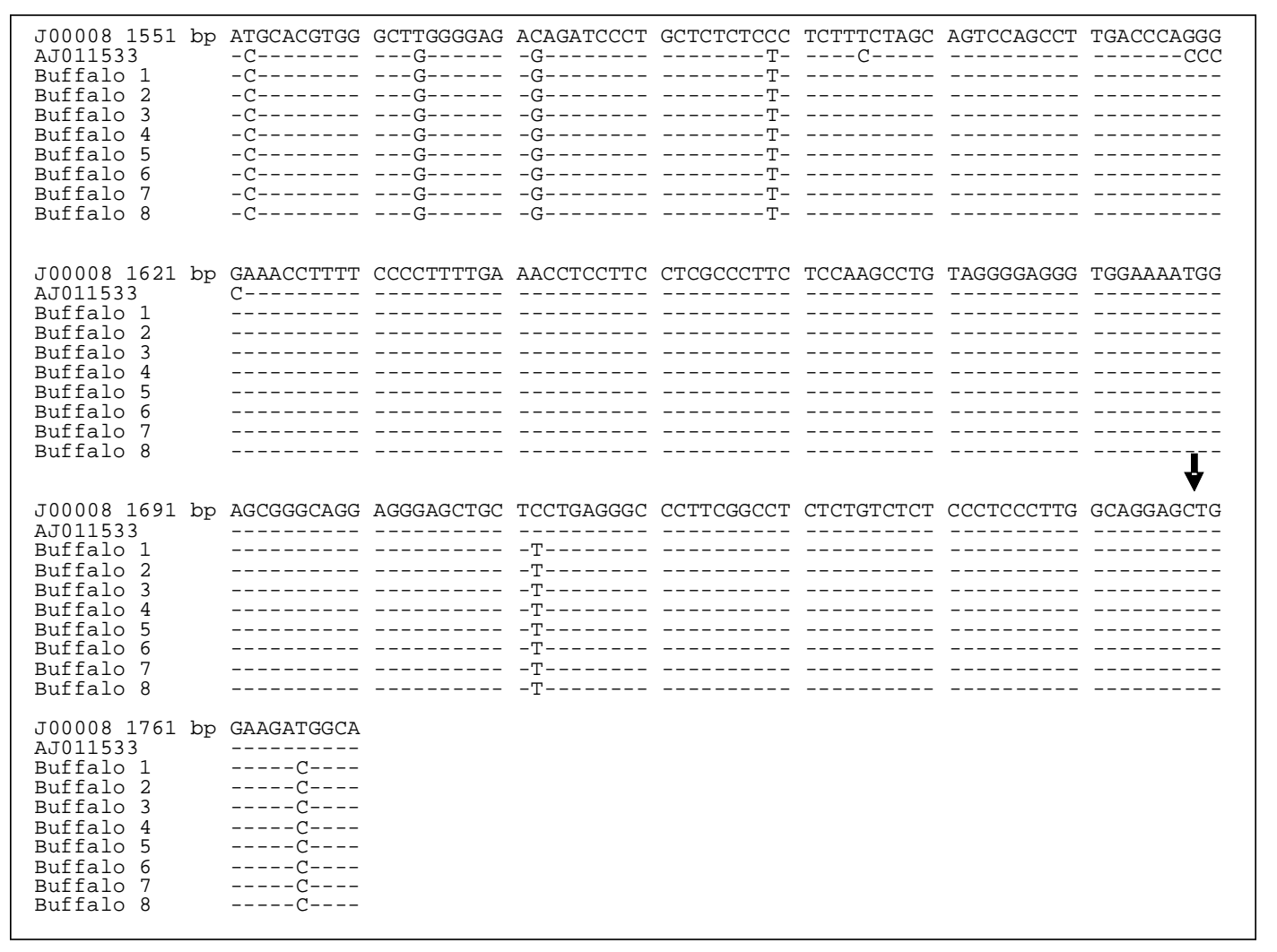

Figure 4. Sequence of GH Gene Fragment. Cattle (J00008, GenBank); Buffalo (AJ011533, GenBank); Buffalo 1-8: Indonesian Buffalo Samples; Point of Mutation $1758(\downarrow)$. Identity with the First Sequence is Denoted by a Dash.

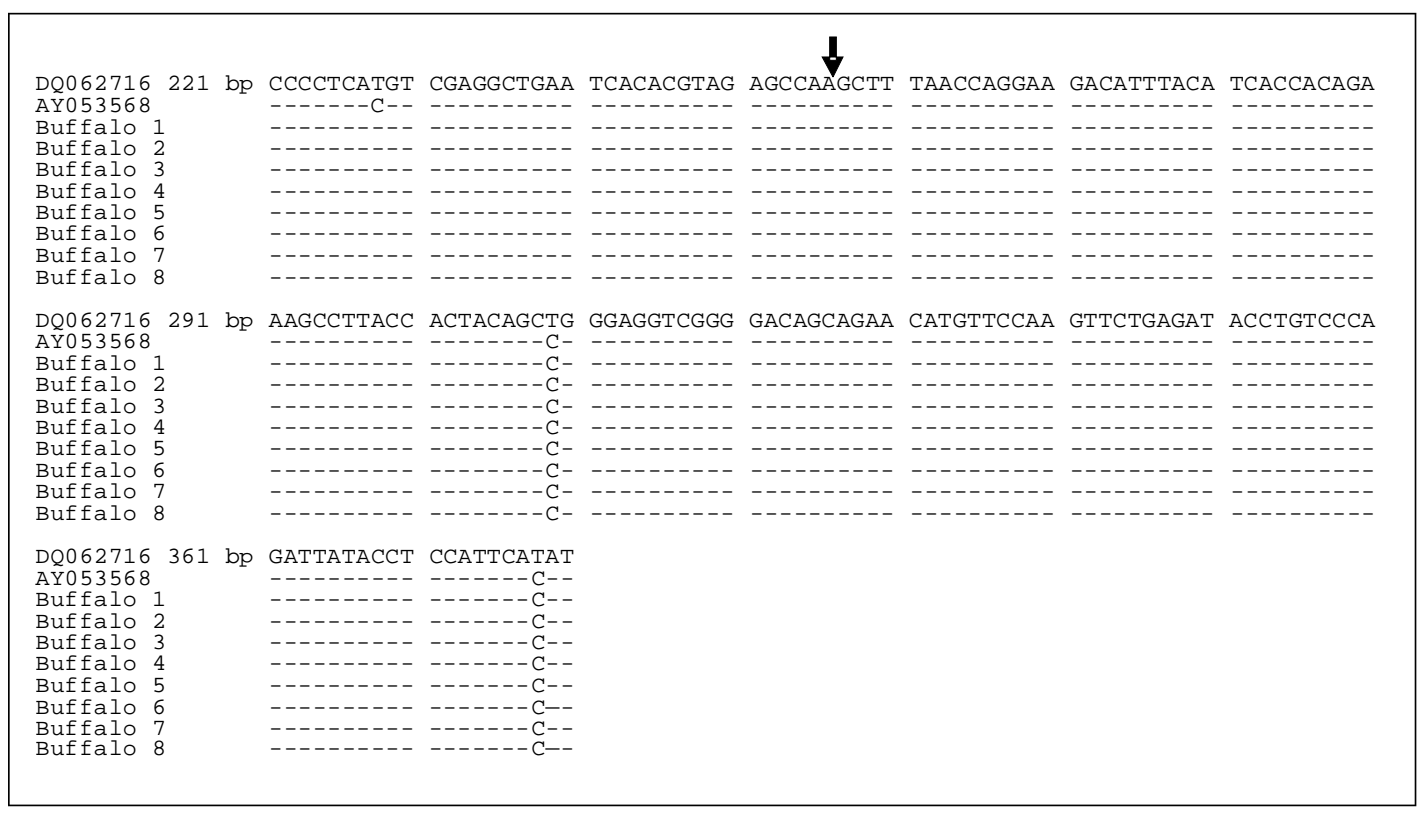

Figure 5. Sequence of GHR Gene Fragment. Cattle (DQ062716, GenBank); Buffalo (AY053568, GenBank); Buffalo 1-8: Indonesian Buffalo Samples; Point of Mutation $256(\downarrow)$. Identity with the First Sequence is Denoted by a Dash. 
Ministry of Agriculture for giving permission collecting buffalo blood samples in North Sumatra, Banten, Central Java, and West Nusa Tenggara Provinces.

\section{REFERENCES}

Akers, R.M. 2006. Major advances associated with hormone and growth factor regulation of mammary growth and lactation in dairy cows. J. Dairy. Sci. 89:1222-12234.

Ardiyanti, A., Y. Oki, Y. Suda, K. Suzuki, K. Chikuni, Y. Obara and K. Katoh. 2009. Effects of GH gene polymorphism and sex on carcass traits and fatty acid compositions in Japanese Black cattle. Anim. Sci. J. 80:6269.

Ayuk, J. and M.C. Sheppard. 2006. Growth hormone and its disorders. Postgrad. Med. J. 82:24-30.

Balogh, O., K. Kovacs, M. Kulcsar, A. Gaspardy, H. Febel, A. Zsolnai, L. Fesus, C. Delavaud, Y. Chilliard, R.O. Gilbert and Gy. Huszenicza. 2009. Interrelationship of growth hormone AluI polymorphism and hyperketonemia with plasma hormones and metabolites in the beginning of lactation in dairy cows. Livestock Sci. 123:180-186.

Barroso, A., S. Dunner and J. Canon. 1999. Technical note: use of PCR-single-strand conformation polymorphism analysis for detection of Bovine $\beta$-casein variants A1, A2, A3, and B. J. Anim. Sci. 77:2629-2632.

Blott, S., J.J. Kim, S. Moisio, A.S. Kuntzel, A. Cornet, P. Berzi, N. Cambiaso, C. Ford, B. Grisart, D. Johnson, L. Karim, P. Simon, R. Snell, R. Spelman, J. Wong, J. Vilkki, M. Georges, F. Farnir and W. Coppeters. 2003. Molecular dissection of a quantitative trait locus: a phenylalanine-to-tyrosine substitution in the transmembrane domain of the bovine growth hormone receptor is associated with a major effect on milk yield and composition. Genet. 163:253-266.

Diyono, R. 2009. Karakteristik Ukuran Tubuh dan Polimorfisme Gen GH, GHRH dan Pit-1 pada Populasi Kerbau di Banten. Tesis. Sekolah Pascasarjana, Institut Pertanian Bogor, Bogor

Di Stasio, L., G. Destefanis, A. Brugiapaglia, A. Albera and A. Rolando. 2005. Polymorphism of the GHR gene in cattle and relationship with meat production and quality. Anim. Genet. 36:138-140.

FAO. 2000. World Watch List for Domestic Animal Diversity, Shere, B.D. (Ed.). Food Agriculture Organization of the United Nations, Rome, Italy.

Ge, W., M.E. Davis, H.C. Hines and K.M. Irvin. 2000. Rapid communication: single nucleotide polymorphisms detected in exon 10 of the bovine growth hormone receptor gene. J. Anim. Sci. 78:2229-2230.

Hayashi, K. 1991. PCR-SSCP: a simple and sensitive method for detection of mutations in the genomic DNA. PCR Methods Appl. 1:34-38.

Lucy, M.C., S.D. Hauser, P.J. Eppard, G.G. Krivi, J.H. Clark, D.E. Bauman and R.J. Collier. 1993. Variants of somatotropin in cattle: gene frequencies in major dairy breeds and associated milk production. Domest. Anim. Endocrinol. 10:325-333.

Nei, M. and S, Kumar. 2000. Molecular Evolution and Phylogenetics. Oxford University Press, New York.

Sambrook, J. and D. Russell. 2001. Molecular Cloning: A Laboratory Manual, $3^{\text {rd }}$ ed. Cold Spring Harbor Laboratory Press, United State of America.

ThidarMyint, H., H. Yoshida, T. Ito, H. Inoe and H. Kuwayama. 2008. Combined administration of ghrelin and GHRH synergistically stimulates $\mathrm{GH}$ release in Holstein preweaning calves. Domest. Anim. Endocrinol. 34:118-123. 